\title{
Türkiye'de İnanç Turizmi Üzerine Nitel Bir Araştırma ${ }^{1}$
}

\author{
Doç. Dr. Nurettin AYAZ \\ Karabük Üniversitesi, Safranbolu Turizm Fakültesi \\ nurettinayaz@karabuk.edu.tr \\ https://orcid.org/ 0000-0003-2117-2015
}

DOI: https://doi.org/10.37847/tdtad.833480

Makale Gönderim Tarihi: 30.11 .2020

\author{
Mehmet EREN \\ Karabük Üniversitesi, Lisansüstü Eğitim Enstitüsü \\ mehmeteren@karabuk.edu.tr \\ https://orcid.org/ 0000-0003-4064-5535
}

Makale Türü: Araştırma Makalesi

Makale Kabul Tarihi: 15.12.2020

\section{Özet}

Dini amaçlı seyahatler, seyahatin en eski ve en yaygın nedenlerinden biridir. Türbeler, tapınaklar, kiliseler, dini yerler ve törenler her zaman bir çekicilik unsuru olmuş, bugün de dini turizm çekicilikleri ile tanınan ve çok sayıda ziyaretçi çeken birçok destinasyon bulunmaktadır. Bu destinasyonlardan üç önemli din (İslamiyet, Hristiyanlık, Musevilik) için dini zenginlikleri bünyesinde bulunduran ülkelerden bir tanesi de Türkiye'dir. Türkiye, inanç turizmi açısından 44 ilindeki çekicilikleri ve inanç turizmi kapsamında yılda en az 250 bin kişiyi ağırlayabilme kapasitesi ile oldukça önemli bir varış noktasıdır. Bu anlamda Türkiye turizminde inanç turizmine yönelik bilimsel çalışmalar önem arz etmektedir. Bu araştırmada Türkiye'de inanç turizmi kapsamında hazırlanmış olan lisansüstü tez çalışmaların anlık bir görüntüsünün ortaya çıkarılması ve ibadetin gereğini yerine getirme, ruhi rahatlama ve kültürel amaçlarla şekillenebilen inanç turizmi konusunda farkındalık oluşturulması amaçlanmaktadır. $\mathrm{Bu}$ amaç doğrultusunda Yükseköğretim Kurumu Ulusal Tez Merkezi veri tabanında "İnanç Turizmi" alanında yayımlanan lisansüstü tezler "bibliyometrik analiz" ve "içerik analizi" teknikleri kullanılarak çeşitli parametreler doğrultusunda analiz edilmektedir. İnanç turizmine yönelik tezlerin büyük çoğunluğu yüksek lisans tezi olup, Sosyal Bilimler Enstitüsü, Turizm İ̧̧letmeciliği Anabilim Dalı bünyesinde hazırlanmıştır. Tezler; alternatif turizm geliştirme, tanıtım, imaj, pazarlama, hizmet kalitesi, etkinlik geliştirme, koruma ve farkındalık oluşturma amaçları ekseninde şekillenmektedir.

Anahtar Kelimeler: İnanç Turizmi, Bibliyometrik Analiz, İçerik Analizi, Lisansüstü Tezler, Türkiye.

\section{A Qualitative Study on Religious Tourism in Turkey}

\begin{abstract}
Religious travel is one of the oldest and most common reasons for travel. Mausoleums, temples, churches, religious places and ceremonies have always been an attraction element, and today there are many destinations that are known for their attraction to religious tourism and attract many visitors. Three major religions of these destinations (Islam, Christianity, Judaism) is also one of the countries with the richest religious site in Turkey. Turkey, within the scope of religious tourism in the province in terms of attractiveness for 44 years and is a very important

\footnotetext{
${ }^{1} \mathrm{Bu}$ makale; Karabük Üniversitesi, Lisansüstü Enstitüsü, Turizm İşletmeciliği Anabilim Dalı'nda yazılan “Türkiye'de İnanç Turizmi ve Geliştirilmesi Üzerine Nitel Bir Araştırma” başlıklı tezden üretilmiştir
} 
destination for religious tourism with capacity to accommodate at least 250 thousand people. In this sense, scientific studies on religious tourism in Turkey's tourism is of great importance. In this research, the discovery of a snapshot of graduate thesis prepared within the scope of faith tourism in Turkey and fulfill the requirements of worship, relaxation and spiritual aims at creating awareness of religious tourism which can be shaped by cultural purposes. For this purpose, graduate theses published in the field of Faith Tourism in the database of National Thesis Center of Higher Education Institution were analyzed in accordance with various parameters using "bibliometric analysis" and "content analysis" techniques. The majority of the theses for faith tourism are master's theses. Thesis; alternative tourism development, promotion, image, marketing, service quality, activity development, protection and awareness-raising aims.

Keywords: Faith Tourism, Bibliometric Analysis, Content Analysis, Postgraduate Thesis, Turkey.

\section{GİRIŞ}

Türk Dil Kurumu tarafından "Tanrı'ya, bir dine inanma, akide, iman, itikat" "bir düşünceye gönülden bağlı bulunma", "inanılan şey, görüş, öğreti" ve "birine duyulan güven, inanma duygusu" olarak ifade edilen "inanç" kelimesi son dönemlerde turizm disiplininde de kendine sıkça yer bulan bir kavram haline gelmekte ve "dini turizm" içerisinde önemini artırmaktadır. Din, uzun zamandan beri seyahatler için birincil bir motivasyon kaynağı olmuş ve seyahat etmenin en eski ekonomik olmayan nedeni olarak kabul edilmiştir. Kısa süreli dini seyahatler, yakındaki hac merkezlerine yapılan geziler ve dini konferanslarla uzun süreli dini seyahatler ise ulusal ve uluslararası hac yerlerini ziyaret ve konferanslarla ilişkilendirilmiştir (Gisbert, 1992: 51; Abbate ve Nuovo, 2013: 501).

Pek çok insanın tutumlarını şekillendiren ve yaşamlarının merkezinde yer alan din, merkezi bir inanç noktasında olmak üzere birçok ritüel, seremoni, pratik ve duaları içerir (Jafari, 2000: 497). $\mathrm{Bu}$ perspektifte farklı dinlere mensup bulunan insanların inandıkları dinin kutsal mekanlarına ziyaretleri önemli bir gerekliliktir. Bu gerekliliğin farkında olan turizm pazarlamacıları, dine yönelen bu bireyler için "inanç turizmi” " başlı̆̆ı altında yeni tanıtım faaliyetlerine yönelmektedir (Gürbüz ve Aydın, 2018).

İnanç turizmi; bir din için kutsal sayılan yerlere ziyaret, toplantı ve törenlere katılma veya bunları izleme, dini görevlerin bir parçası olan "hac" ibadetini yerine getirme gibi nedenlerle ortaya çıkan seyahat ve konaklamaların oluşturduğu bir turizm olayı olarak değerlendirilmektedir. İnanç turizmi, farklı dinlere mensup bulunan turistlerin çeşitli dini nedenlerle (kutsal sayılan yerlerin ziyaret edilmesi, dini inançları gereği olan ibadetlerin gerçekleştirilmesi) yapılan geziler olarak da görülmektedir (Karaman vd., 2008: 210). Belirli inançların izleyicileri olarak bu gezilere katılan turistler, turizm endüstrisinde "özel ilgi turizmi" olarak adlandırılan turizm çeşidinin önemli bir parçası olarak da görülebilir. Ayrıca, maneviyat yönüyle inanç turizmi, turizmde ekonomik istikrarsızlıktan sağılık turizmiyle birlikte en az etkilenen turizm çeşitleri arasında yer almaktadır.

Turizm literatüründe dini turizme yönelik araştırmalar, genellikle farklı yazarlar tarafindan kültürel miras turizmi, kültür turizmi ve inanç turizmi kapsamında çeşitlenmektedir. Bununla birlikte "inanç turizmi" kapsamında lisansüstü tezlere yönelik hem bibliyometrik analiz hem de içerik analizine birlikte yer veren herhangi bir çalışmaya rastlanılmamaktadır. Bu çalışma, lisansüstü tezlere inanç turizmi perspektifinden bir bakış açısı geliştirme, Türkiye'de inanç turizminin gelişimine katkı sağlama ve farkındalık oluşturma yönleri ile farklılık arz etmektedir. Türkiye' de inanç turizmine yönelik gelecek zamanlarda yapılacak bilimsel çalışmalarına yol gösterme yönüyle çalışma önem arz etmektedir.

December-2020 Vol:5 No:2 International Journal of Turkic World Tourism Studies 


\section{ÍLGILİ LITERATÜR}

İnsanların dini öneme sahip yerlere neden seyahat ettiklerinin belirlenmesi, turizmde incelenmesi gereken önemli bir sorudur. Dinin, seyahat artışındaki rolü ve teşvik edici yönünün öne çıkartılması, dini destinasyonların yönetimi ve sürdürülebilirliğinde önemli çıktılardır (UNWTO, 2008). Bu durumun sonucu olarak son yıllarda inanç turizmi, çok araştırılmaya başlanan bir turizm çeşidi haline gelmektedir. İnanç turizmindeki büyüme, diğer turizm pazarlarıyla karşılaştırıldığında şaşırtıcı düzeydedir (Timothy ve Olsen, 2006).

Sosyal kurumlardan bir tanesi olarak kabul edilen din; kişilerin/toplumların tutum, değer ve davranışlarında önemli etkiye sahip bir ihtiyaçtır (Mokhlis, 2009). Bu ihtiyaç çerçevesinde din ve dindarlık hakkında daha fazla bilgi isteği her geçen gün artmakta, gelişmiş ve gelişmekte olan birçok ülke din turizmden kazanç payını artırma isteği taşımaktadır (El-Gohary, 2016).

İnanç turizmi, genellikle kutsal alan olarak kabul edilen yerleri ziyaret eden, belirli inançların izleyicileri ile ilgili olan ve "özel ilgi turizmi" olarak adlandırılan turizm endüstrisinin önemli bir parçasıdır. Aynı zamanda genellikle kültürel turizmin bir parçası olarak da kabul edilir ve mevsimsel dalgalanmalardan çok az etkilenme özelliği ile öne çıkar. İnanç turizmi; dini inanç, kültürel zevk ve zihinsel rahatlama etrafında şekillenen bir turizm çeşidi olup, dini inançlar ve zihinsel rahatlama itme; kültürel zevk ise çekme faktörlerini oluşturur (Wang vd., 2016: 57).

Dini turizmi her şekilde teşvik etmek ve tüm dünyada daha iyi seyahat etmek adına eğitim ve bilgi sağlamak için Dünya Dini Seyahat Birliği (WRTA) kurulmuştur. Uzmanlara göre dini turizm sektörü, gelecekte daha fazla gelişme potansiyeline sahiptir. Bu nedenle inanç turizmi sadece ulusal ve bölgesel hükümetlerin değil akademik alan için de ilgi konusudur. Avrupa Birliği (AB) ülkelerindeki birçok bölge; dini turizmin varış yerleri, önemli dini tarihi olayları ve ilgili önemli kutsal binaların, nesnelerin veya anıtların konumu veya varlı̆g 1 gibi konularda din turizmi stratejilerini oluşturmuştur (https://is.mendelu.cz). Bununla birlikte dünya çapında dini alanlara yapılan seyahatlerin hızla artmasına rağmen, bu alanlardaki turistlerin seyahat nedenleri, ilgi alanları ve ihtiyaçları hakkında yeterli bilgiye sahip olunmadığı düşünülmektedir (Hughes, vd., 2013).

Türkiye, inanç turizmi kapsamında son yıllarda önemini artıran bir destinasyon konumundadır. "Semavi Dinler" olarak adlandırılan Yahudilik, Hristiyanlık ve İslamiyet kapsamında bu dinlere mensup inananların inançlarının gereğini yerine getirebilme imkanı sunma açısından kutsal mekanlara sahip bir ülkedir. Türkiye'de de Kültür ve Turizm Bakanlığı "İnanç Turizmi Projesi" çerçevesinde, üç önemli semavi dine (Müslümanlık-Hıristiyanlık-Musevilik) ait olmak üzere ve bugüne kadar ulaşmış olan ziyaret merkezlerinde ulaşım, aydınlatma, çevre düzenlemesi vb. düzenlemeler ve ziyaretçi sayısının artırılmasına yönelik tanıtımlar yürütülmektedir. $\mathrm{Bu}$ çerçevede 1993 yılında öncelikle üç büyük dine yönelik eserlerin ve ibadet yerlerinin envanteri hazırlanmış ve öne çıkan kıyı turizminin sağlı, kültür ve inanç turizmi gibi alternatif turizm çeşitlendirilmesi beklenmektedir. Bu anlamda Trabzon Sümela Manastırı ve Van Akdamar Kilisesi'nin 2010 yılında ibadete açılması dünyanın her tarafından turist akışına neden olmuştur. Türkiye' deki pek çok mekânın (Efes, İznik, Antakya, İstanbul vb.) kutsal sayılması da turist akışını artırmaktadır (Okuyucu ve Somuncu, 2013; https://cemalakin.wordpress.com). Mevlana ve Hacı Bektaşi Veli gibi önemli dini bilgelerin yanına Hacı Bayram Veli, Hz. Pir Şeyh Şaban-1 Veli gibi şahsiyetlerde inanç turizminin güçlendirilmesi beklenmektedir (Avc1, 2019). Bununla birlikte Türkiye' de turizm literatürü kapsamında "İnanç Turizmi”" konulu çalışmaların çok sınırlı sayıda olduğu ve dağınık bir görünüm sergilediği söylenebilir.

Koçoğlu ve arkadaşları (2019) tarafindan yapılan çalışmada Türkiye'de turizmin sürdürülebilirliğine katk1 sağlayabilecek alternatif turizm çeşitleri arasında inanç turizmi de 
gösterilmekte ve bu turizm çeşidinin sürdürülebilirliği için yatırım planlamalarında yerel halkın görüşlerinin dikkate alınmasına ve inanç turizmine özgü yerleri sembolize edebilecek broşür, doküman ve hediyelik eşya benzeri ürünlerin hazırlanmasına dikkat çekilmektedir. Kim ve Kim (2019) ise inanç turizmi kapsamında seyahat eden turistler için hiyerarşik bir değer haritası oluşturulması ve bu haritada turistlerin ziyaret ettikleri yerlerin özellikleri, aradığ 1 faydalar ve kendi kişisel değerleri açısından dini yerleri nasıl algıladıklarına yer verilmesine vurgu yapmaktadır. Aslantürk ve arkadaşları (2013) tarafından gerçekleştirilen "İnanç Turizmi İle İlgili Türkiye'de Yapılan Akademik Çalışmaların İncelenmesi” başlıklı araştırma çalışmasında inanç temalı seyahatlerin turizm kapsamında değerlendirilmesinde akademik çalışmaların teorik ve sektörel gerekliliğine dikkat çekilmektedir. 1998-2013 yılları arasında inanç turizmine yönelik makale ve tezlerin yöntem ve içerik açısından değerlendirildiği çalışmada, hazırlanan çalışmaların çoğunlukla betimleyici çalışmalar olduğu, sektörü ve ilgili literatürü destekleyici çalışmalara ihtiyaç bulunduğu yönündedir.

\section{YÖNTEM}

$\mathrm{Bu}$ araştırmada Yükseköğretim Kurumu Ulusal Tez Merkezi (YÖK-UTM) veri tabanında "İnanç Turizmi" alanında yayımlanan lisansüstü tezlerin nitel araştırma yöntemi kapsamında "bibliyometrik analiz" ve "içerik analizi" teknikleri kullanılarak çeşitli parametreler doğrultusunda analizi öngörülmekte ve inanç turizmi ile ilgili yazılan lisansüstü tezlerin anlık görüntüsünün okuyucuya sağlanarak, bilgisinin arttırılması amaçlanmaktadır.

Tezlerin bibliyometrik analizinde Ruiz-Real ve arkadaşları (2018) tarafından gerçekleştirilen çalışmada belirtilen (1) arama kriterlerini, anahtar kelimeleri ve zaman periyotlarını tanımlamak; (2) Web veri tabanının seçilmesi; (3) araştırma kriterlerinin düzenlenmesi ve iyileştirilmesi; (4) nihai verinin dışa aktarımı; (5) bilginin analizi ve sonuçların tartışılması adımlarına başvurulmuştur. Tezlerin içerik analizinde ise Harris (2001) tarafından önerilen (1) araştırma sorusunun/sorularının belirlenmesi, (2) örneklem, (3) analiz birimlerinin belirlenmesi, (4) kullanılacak kategorilerin saptanması, (5) kodlamanın yapılması, (6) geçerlilik ve güvenirliğin tespit edilmesi aşamaları esas alınmıştır.

Tablo 1. İnanç Turizmine Yönelik Tezlere İlişkin Geçerlilik ve Güvenirlik Analizi

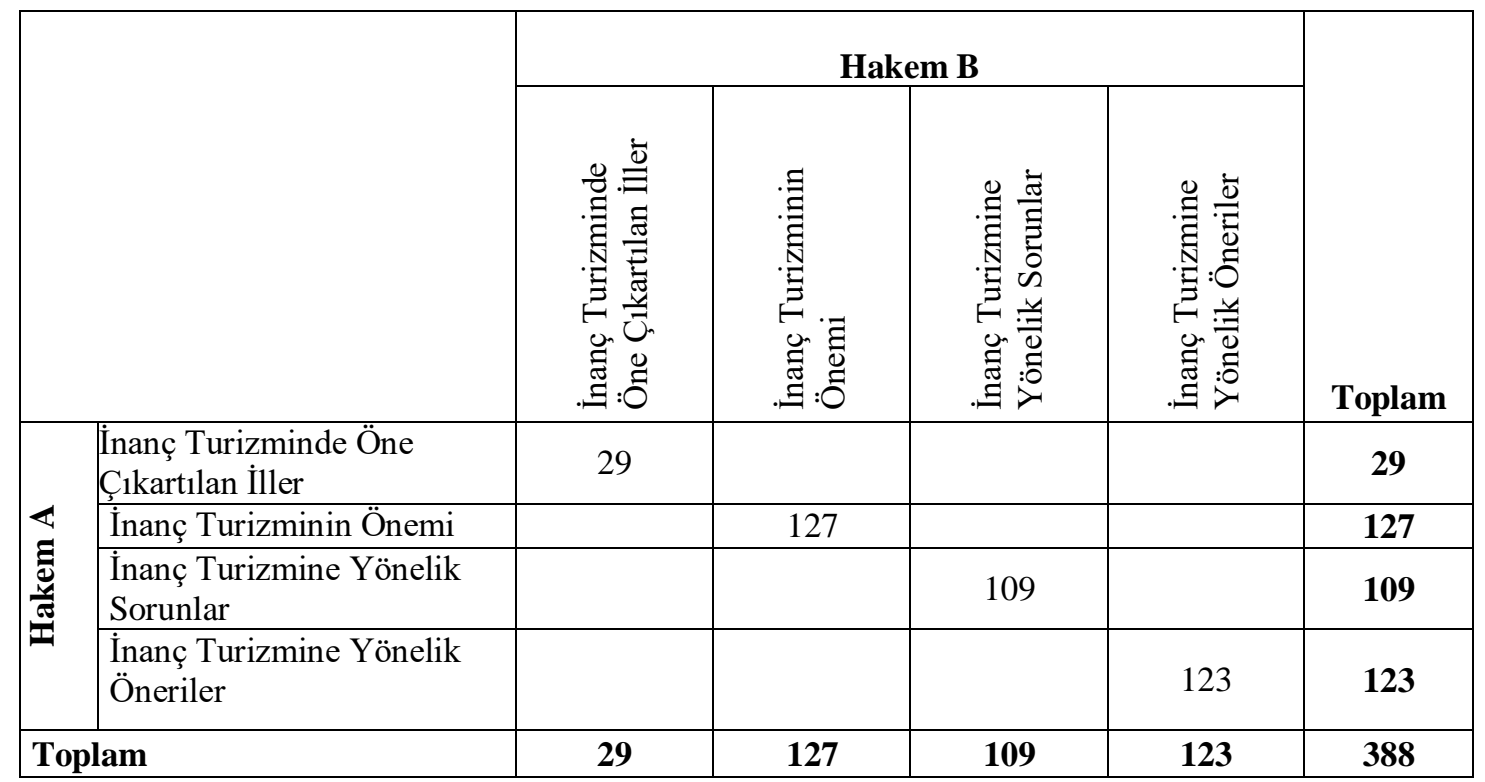

Kappa: $1 \quad \mathbf{p}=\mathbf{0 , 0 0 0}$

December-2020 Vol:5 No:2 International Journal of Turkic World Tourism Studies 
Türkiye' de inanç turizmine yönelik olarak hazırlanmış olan lisans üstü tezlerin içerik analizi kapsamında tema kodları "il, önem, sorun ve öneri" olarak belirlenmiştir. Bu tema kodları çerçevesinde 47 adet tez tamamen, erişime kapalı olan 4 adet ise özet boyutu ile içerik analizi çalışmasına dahil edilmiştir. Tezler kapsamında inanç turizmi ile ilişkilendirilmiş toplam 388 ifadeye ulaşılmıştır. Ulaşılan ifadelerin geçerlilik ve güvenilirliği kapsamında iki araştırmacıdan bu ifadeleri "Türkiye'de İnanç Turizmi Açısından Öne Çıkartılan İller”, "Türkiye'nin İnanç Turizmi Açısından Önemi”, “Türkiye'de İnanç Turizmine Yönelik Sorunlar”, ve "Türkiye'de İnanç Turizmi Geliştirilmesine Yönelik Öneriler" kategorilerinde kodlama yapılması istenmiştir. Kategorilere ilişkin kodlama sonuçları kapsamında Tablo 1'deki sonuçlarına ulaşılmıştır.

Tablo 1 sonuçlarına göre Araştırmacı A; inanç turizminde öne çıkarılan illerle ilgili 29, inanç turizminin önemi ile ilgili 127, inanç turizmine yönelik sorunlar ile ilgili 109, inanç turizminin geliştirilmesine yönelik önerilerle ilgili 123 karar için onay vermiştir. Araştırmacı B'de inanç turizminde öne çıkarılan illerle ilgili 29, inanç turizminin önemi ile ilgili 127, inanç turizmine yönelik sorunlar ile ilgili 109, inanç turizmine yönelik öneriler ile ilgili 123 karar için onay vermiştir. $\mathrm{Bu}$ değerlendirmelerin geçerliliği ve güvenirliği kapsamında "Kappa Analizi" yapılmıştır. Çalışmanın Kappa $=1$ ve anlamlılık düzeyi $p<0,001$ altında olduğu görülmüştür. $B u$ sonuçlar çerçevesinde çalışmanın geçerli ve güvenilir olduğuna karar verilmiştir. Ayaz (2015), Kappa Analizi için 0,41-0,60 arasını orta, 0,61-0,80 arası önemli, 0,81-1,00 arası ise oldukça önemli bir güvenirliğe sahip olduğunu belirtmektedir.

\section{BULGULAR}

Türkiye'de 1996-2019 döneminde inanç turizmi kapsamında hazırlanmış lisansüstü tezlerin nitel araştırma yöntemi çerçevesinde analizinde ilk olarak YÖK-UTM içerisindeki inanç turizmi, helal turizm ve dini turizm başlıklı lisansüstü tezlerin tez türlerine yönelik dağılımında (Tablo 2) tezlerin \%94,1'inin yüksek lisans, \%5,9'nun doktora tezinden oluştuğu tespit edilmiştir.

Tablo 2. Lisansüstü Tezlerin Türlerine Göre Dağılımı

\begin{tabular}{lrrr}
\hline Tez Türü & $\mathbf{n}$ & $\mathbf{\%}$ \\
\hline Yüksek Lisans & 48 & 94,1 \\
\hline Doktora & 3 & 5,9 \\
\hline Toplam & $\mathbf{5 1}$ & $\mathbf{1 0 0}$ \\
\hline
\end{tabular}

Lisansüstü tezlerin yıllara bazında kronolojik dağılımında (Tablo 3) 2019 y1lı 12 tez (\%24,6) ile öne çıkan dönem olmuştur. Bu tezlerin tamamı yüksek lisans tezi olarak hazırlanmıştır. Tez türü toplamında ikinci sırada 8 adet $(\% 15,6)$ tezle 2017 yılı yer almıştır. Bu tezlerin 6 adeti yüksek lisans $(11,8)$, ve 2 adeti doktora $(\% 3,8)$ tezi kapsamında hazırlanmıştır. Üçüncü sırada ise 5 adet yüksek lisans tezi $(\% 9,8)$ ile 2014 yılı olmuştur. Bu bulgular kapsamında Türkiye' de inanç turizmine yönelik akademik araştırmaların 2014 yılından sonra popülerlik kazandığı söylenebilir. Bununla birlikte sadece 2 adet doktora tezinin bulunması inanç turizmi açısından doktora eğitimi düzeyinde yeterli olmadığı şeklinde değerlendirilebilir. 
Tablo 3. Lisansüstü Tezlerin Y1llara Göre Dağılımı

\begin{tabular}{|c|c|c|c|c|c|c|}
\hline \multirow[t]{3}{*}{ Yayınlandığı Yıl } & \multicolumn{4}{|c|}{ Tez Türü } & & \\
\hline & \multicolumn{2}{|c|}{ Yüksek Lisans } & \multicolumn{2}{|r|}{ Doktora } & \multicolumn{2}{|c|}{ Toplam } \\
\hline & $\mathbf{n}$ & $\%$ & $\mathbf{n}$ & $\%$ & $\mathbf{n}$ & $\%$ \\
\hline 1996 & 1 & 2 & - & - & 1 & 1,9 \\
\hline 1998 & 1 & 2 & - & - & 1 & 1,9 \\
\hline 2000 & 1 & 2 & - & - & 1 & 1,9 \\
\hline 2005 & 1 & 2 & - & - & 1 & 1,9 \\
\hline 2009 & 1 & 2 & 1 & 33,3 & 2 & 3,8 \\
\hline 2010 & 3 & 6,4 & - & - & 3 & 5,8 \\
\hline 2011 & 3 & 6,4 & - & - & 3 & 5,8 \\
\hline 2012 & 2 & 4 & - & - & 2 & 3,8 \\
\hline 2013 & 2 & 4 & - & - & 2 & 3,8 \\
\hline 2014 & 5 & 10,4 & - & - & 5 & 9,8 \\
\hline 2015 & 3 & 6,4 & - & - & 3 & $\overline{5,8}$ \\
\hline 2016 & 3 & 6,4 & - & - & 3 & 5,8 \\
\hline 2017 & 6 & 12,5 & 2 & 66,7 & 8 & 15,6 \\
\hline 2018 & 4 & 8,5 & - & - & 4 & 7,8 \\
\hline 2019 & 12 & 25 & & & 12 & 24,6 \\
\hline Toplam & 48 & 100 & 3 & 100 & 51 & 100 \\
\hline
\end{tabular}

İnanç turizmi konu alan lisansüstü yayım diline göre dağılımında (Tablo 4) 51 tezin tamamının (\%100) Türkçe olarak hazırlandığı tespit edilmiştir. Bu durum Türkiye'deki inanç turizminin dünya genelinde tanınmasında önemli bir eksiklik olarak görülebilir ve üniversite anabilim dallarının inanç turizmine yönelik farklı yabancı dillerde tezler hazırlaması önerilebilir.

Tablo 4. Lisansüstü Tezlerin Yayım Diline Göre Dağılımı

\begin{tabular}{lrrrrrrr}
\hline \multirow{2}{*}{ Yayım Dili } & \multicolumn{4}{c}{ Dil } & \multicolumn{2}{c}{ Toplam } \\
\cline { 2 - 7 } & \multicolumn{2}{c}{ Yüksek Lisans } & \multicolumn{2}{c}{ Doktora } & \multicolumn{2}{c}{} \\
\cline { 2 - 7 } & $\mathbf{n}$ & $\mathbf{\%}$ & $\mathbf{n}$ & $\mathbf{\%}$ & $\mathbf{n}$ & $\boldsymbol{\%}$ \\
\hline Türkçe & 48 & 94,3 & 3 & 5,7 & 51 & 100 \\
\hline İngilizce & - & - & - & - & - & - \\
\hline Toplam & $\mathbf{5 1}$ & $\mathbf{1 0 0}$ & - & - & $\mathbf{5 1}$ & $\mathbf{1 0 0}$ \\
\hline
\end{tabular}

İnanç turizmine yönelik olarak hazırlanan lisansüstü tezlerinin hazırlandığı üniversitelere göre dağglımında (Tablo 5) en fazla lisansüstü tez çalışan üniversiteler; Dokuz Eylül Üniversitesi (6), Gazi Üniversitesi (5) ve Kastamonu Üniversitesi (5) olarak belirlenmiştir. 
Tablo 5. Lisansüstü Tezlerin Üniversitelere Göre Dağılımı

\begin{tabular}{|c|c|c|c|c|c|c|}
\hline \multirow[t]{2}{*}{ Hazırlandığı Üniversite } & \multicolumn{2}{|c|}{ Yüksek Lisans } & \multicolumn{2}{|c|}{ Doktora } & \multicolumn{2}{|c|}{ Toplam } \\
\hline & $\mathrm{n}$ & $\%$ & $\mathrm{n}$ & $\%$ & $\mathrm{n}$ & $\%$ \\
\hline Adnan Menderes Üniversitesi & 1 & & - & - & 1 & \\
\hline Akdeniz Üniversitesi & 1 & & - & - & 1 & \\
\hline Balıkesir Üniversitesi & 3 & - & - & - & 3 & \\
\hline Batman Üniversitesi & 1 & & - & - & 1 & \\
\hline Dicle Üniversitesi & 1 & & - & - & 1 & \\
\hline Dokuz Eylül Üniversitesi & 5 & & 1 & & 6 & \\
\hline Düzce Üniversitesi & 1 & & - & - & 1 & \\
\hline Ege Üniversitesi & 1 & & - & - & 1 & \\
\hline Gazi Üniversitesi & 5 & & - & - & 5 & \\
\hline Gaziantep Üniversitesi & 1 & & - & - & 1 & \\
\hline Hasan Kalyoncu Üniversitesi & 1 & & - & - & 1 & \\
\hline İstanbul Üniversitesi & 4 & & - & - & 4 & \\
\hline Karabük Üniversitesi & 1 & & - & - & 1 & \\
\hline Karamanoğlu Mehmet Bey Üniversitesi & 1 & & - & - & 1 & \\
\hline Kastamonu Üniversitesi & 5 & & - & - & 5 & \\
\hline Kırklareli Üniversitesi & 1 & & - & - & 1 & \\
\hline Marmara Üniversitesi & 1 & & 1 & & 2 & \\
\hline Mersin Üniversitesi & 1 & & - & - & 1 & \\
\hline Mimar Sinan Güzel Sanatlar Üniversitesi & 1 & & - & - & 1 & \\
\hline Muğla Sitk1 Koçman Üniversitesi & 2 & & - & - & 2 & \\
\hline Necmettin Erbakan Üniversitesi & 2 & & - & - & 2 & \\
\hline Nevşehir Hacı Bektaş Veli Üniversitesi & 1 & & - & - & 1 & \\
\hline Nuh Naci Yazgan Üniversitesi & 1 & & - & - & 1 & \\
\hline Sakarya Üniversitesi & 2 & & 1 & - & 3 & \\
\hline Selçuk Üniversitesi & 1 & & - & - & 1 & \\
\hline Süleyman Demirel Üniversitesi & 1 & & - & - & 1 & \\
\hline
\end{tabular}




\begin{tabular}{lccc}
\hline Trakya Üniversitesi & 1 & - & 1 \\
\hline Türk Hava Kurumu Üniversitesi & 1 & - & - \\
\hline Toplam & $\mathbf{4 8}$ & $\mathbf{3}$ & $\mathbf{5 1}$ \\
\hline
\end{tabular}

İnanç turizmine yönelik olarak hazırlanan lisansüstü tezlerin bağlı olduğu enstitüye göre dağglımında (Tablo 6) tezlerin 1 tanesi Fen Bilimleri Enstitüsünde 50 tanesi ise Sosyal Bilimler Enstitüsü bünyesinde hazırlanmıştır.

Tablo 6. Lisansüstü Tezlerin Enstitülere Göre Dağılımı

\begin{tabular}{lcccccc}
\hline Hazırlandığı Enstitü & \multicolumn{2}{c}{ Yüksek Lisans } & \multicolumn{2}{c}{ Doktora } & \multicolumn{2}{c}{ Toplam } \\
\cline { 2 - 7 } & $\mathbf{n}$ & $\mathbf{\%}$ & $\mathbf{n}$ & $\mathbf{\%}$ & $\mathbf{n}$ & $\mathbf{\%}$ \\
\hline Fen Bilimleri Enstitüsü & 1 & 2,8 & - & - & $\mathbf{1}$ & $\mathbf{1 , 9}$ \\
\hline Sosyal Bilimler Enstitüsü & 47 & 97,2 & 3 & 100 & $\mathbf{5 0}$ & $\mathbf{9 8 , 1}$ \\
\hline Toplam & $\mathbf{4 8}$ & $\mathbf{1 0 0}$ & $\mathbf{3}$ & $\mathbf{1 0 0}$ & $\mathbf{5 1}$ & $\mathbf{1 0 0}$ \\
\hline
\end{tabular}

İnanç turizmine yönelik olarak hazırlanan lisansüstü tezlerin enstitü anabilim dallarına göre dağılımında (Tabl0 7) yüksek lisans tezleri için ilk sırada 34 adet tez ile Turizm İşletmeciliği $\mathrm{ABD} /$ Turizm İşletmeciliği Eğitimi ABD/ Turizm İşletmeciliği ve Otelcilik ABD/ Turizm ve Otel İşletmeciliği ABD, ikinci sırada 7 adet tez ile İşletme ABD ve üçüncü sırada 2 adet tez ile Coğrafya Anabilim Dalı yer almıştır. Doktora tezlerinin içinse 2 adet tez ile Turizm İşletmeciliği ABD öne çıkmıştır. Bunu 1 adet tez ile Üretim Yönetimi ve Pazarlama ABD izlemiştir.

Tablo 7. Lisansüstü Tezlerin Anabilim Dallarına Göre Dağılımı

\begin{tabular}{|c|c|c|c|c|c|c|}
\hline \multirow[t]{2}{*}{ Hazırlandığı Anabilim Dalı } & \multicolumn{2}{|c|}{ Yüksek Lisans } & \multicolumn{2}{|c|}{ Doktora } & \multicolumn{2}{|c|}{ Toplam } \\
\hline & $\mathrm{n}$ & $\%$ & $\mathrm{n}$ & $\%$ & $\mathrm{n}$ & $\%$ \\
\hline Coğrafya Anabilim Dalı & 2 & 4,1 & - & - & 2 & 3,9 \\
\hline Felsefe ve Din Bilimleri Anabilim Dalı & 1 & 2,0 & - & - & 1 & 1,9 \\
\hline İstanbul Araştırmaları Anabilim Dalı & 1 & 2,0 & - & - & 1 & 1,9 \\
\hline İşletme Anabilim Dalı & 7 & 15,5 & - & - & 7 & 15,7 \\
\hline Kültürel Miras Alanlarının Yönetimi ABD & 1 & 2,0 & - & - & 1 & 1,9 \\
\hline Maliye ve Ekonomi ABD & 1 & 2,0 & - & & 1 & 1,9 \\
\hline Mimarlık ABD & 1 & 2,0 & - & - & 1 & 1,9 \\
\hline Sanat Tarihi ABD & 1 & 2,0 & - & - & 1 & 1,9 \\
\hline Turizm İşletmeciliği ABD & 23 & 48,9 & 2 & 66,7 & 25 & 49,0 \\
\hline Turizm İşletmeciliği Eğitimi ABD & 3 & 6,2 & - & - & 3 & 5,8 \\
\hline Turizm İşletmeciliği ve Otelcilik ABD & 5 & 11,3 & - & - & 5 & 10,4 \\
\hline Turizm ve Otel İşletmeciliği ABD & 1 & 2,0 & & & 1 & 1,9 \\
\hline
\end{tabular}




\begin{tabular}{lrrrrrr}
\hline Üretim Yönetimi ve Pazarlama ABD & - & 0 & 1 & 33,3 & 1 & 1,9 \\
\hline Toplam & $\mathbf{4 8}$ & & $\mathbf{3}$ & $\mathbf{1 0 0}$ & $\mathbf{5 1}$ & $\mathbf{1 0 0}$ \\
\hline
\end{tabular}

İnanç turizmine yönelik olarak hazırlanan lisansüstü tezlerin danışmanlarının akademik unvanına göre dağılımında (Tablo 8) Profesör unvanı akademisyenlerin denetiminde hazırlanan lisansüstü tezlerin 3 tanesi $(\% 100)$ doktora ve 17 tanesi $(\% 35,4)$ yüksek lisans tezidir. Doçent ünvanlı danışmaların gözetiminde hazırlanan 10 adet tez $(\% 20,8)$ ile Doktor Ögretim Üyesi/Yardımcı Doçent Doktor danışmanlığında hazırlanan 21 tez $(\% 43,8)$ yüksek lisans tezi kapsamında olduğu belirlenmiştir.

Tablo 8. Lisansüstü Tezlerin Tez Danışmanının Akademik Unvanına Göre Dağılımı

\begin{tabular}{|c|c|c|c|c|c|c|}
\hline \multirow[t]{2}{*}{ Danışman Unvanı } & \multicolumn{2}{|c|}{ Yüksek Lisans } & \multicolumn{2}{|c|}{ Doktora } & \multicolumn{2}{|c|}{ Toplam } \\
\hline & $\bar{n}$ & $\%$ & $\mathbf{n}$ & $\%$ & $\mathbf{n}$ & $\%$ \\
\hline Profesör & 17 & 35,4 & 3 & 100 & 20 & 39,2 \\
\hline Doçent & 10 & 20,8 & - & - & 10 & 19,6 \\
\hline Dr. Öğretim Üyesi/Yrd. Doç. Dr. & 21 & 43,8 & - & - & 21 & 41,2 \\
\hline Toplam & 48 & 100 & 3 & 100 & 51 & 100 \\
\hline
\end{tabular}

İnanç turizmine yönelik lisansüstü tezlerin sayfa sayılarında (Tablo 9) doktora tezlerinde 100150 sayfa aralığında 1 adet $(\% 33,3), 201-250$ sayfa aralığında 1 adet $(\% 33,3)$ ve 251-300 sayfa aralığında 1 adet $(\% 33,4)$, olmak üzere tezler dağılım göstermiştir. Yüksek lisans tezleri ise 50100 sayfa aralığında 11 adet $(\% 22,9), 101-150$ sayfa aralığında 22 adet $(\% 45,8), 151-200$ sayfa aralığında 9 adet $(\% 18,7), 201-250$ sayfa aralığında 4 adet $(\% 8,6), 251-300$ sayfa aralığında 1 adet $(\% 2,0)$ ve 301-350 sayfa aralığında 1 adet $(\% 2,0)$ tez hazırlandığ1 görülmüştür. Bu bilgiler çerçevesinde doktora tezlerinin 100-300 sayfa aralığında hazırladığı ve yüksek lisans tezlerinin ise 100-150 sayfa arasında dağılım gösterdiği söylenebilir.

Tablo 9. Lisansüstü Tezlerin Sayfa Sayılarına Göre Dağılımı

\begin{tabular}{lrrrrrrr}
\hline Sayfa Sayısı & \multicolumn{3}{c}{ Tez Türü } & \multicolumn{2}{c}{ Toplam } \\
\cline { 2 - 5 } & \multicolumn{3}{c}{ Yüksek Lisans } & Doktora & \multicolumn{2}{c}{ n } & \% \\
\cline { 2 - 5 } & 11 & 22,9 & - & - & 11 & 21,5 \\
\hline $50-100$ & 22 & 45,8 & 1 & 0,33 & 23 & 45,0 \\
\hline $101-150$ & 9 & 18,7 & - & - & 9 & 17,9 \\
\hline $151-200$ & 4 & 8,6 & 1 & 0,33 & 5 & 9,8 \\
\hline $201-250$ & 1 & 2,0 & 1 & 0,34 & 2 & 3,9 \\
\hline $251-300$ & 1 & 2,0 & - & - & 1 & 1,9 \\
\hline $301-350$ & $\mathbf{n}$ & $\mathbf{1 0 0}$ & $\mathbf{3}$ & $\mathbf{1 0 0}$ & $\mathbf{5 1}$ & $\mathbf{1 0 0}$ \\
\hline Toplam & & & & & $\mathbf{\%}$
\end{tabular}

İnanç turizmine yönelik tezlerin arama referans kelimelerine göre dağllımında (Tablo 10) 10'da YÖK-UTM veri tabanına tez başlıklarında en çok kullanılan referans kelimesi inanç turizmi 
$(\% 92,2)$ olmuştur. Bu kelimeyi dini turizm $(\% 3,9)$ ve helal turizm $(\% 3,9)$ referans kelimeleri izlemiştir.

Tablo 10. Lisansüstü Tezlerin Arama Referans Kelimelerine Göre Dağılımı

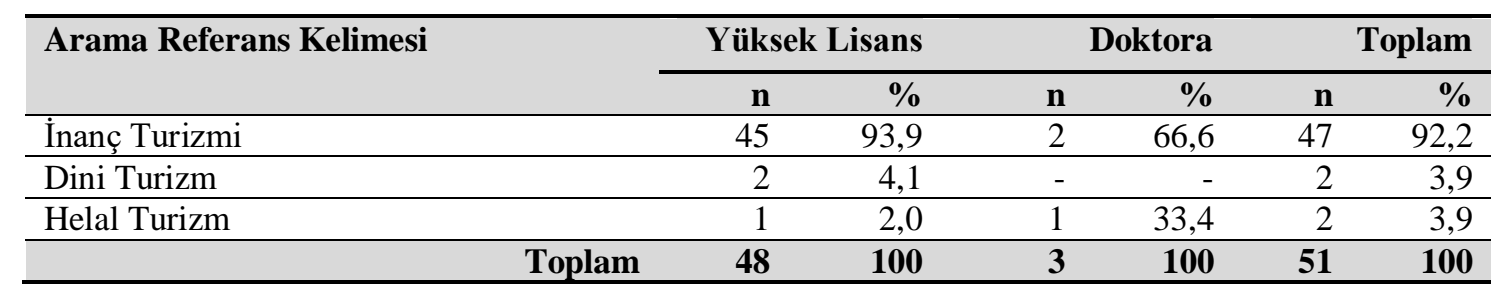

Lisansüstü tezlerin araştırma yöntemlerine göre dağılımında (Tablo 11) toplam 51 adet tezden 3 tanesinde yayın kıstı bulunduğu için 48 adet lisansüstü tezin araştırma yöntemine yer verilmiştir. İnanç turizmini konu alan yüksek lisans tezlerin $\% 62,2$ 'sinde nicel, $\% 22,3$ nitel ve $\% 2,2$ 'sinin nicel-nitel yöntemde hazırlandığ 1 tespit edilmiştir. Doktora tezlerinde ise nicel, nitel ve nicel-nitel yöntemler \%33,3 oranlarında olmak üzere kullanılmıştır. Bununla birlikte lisansüstü tezlerin $\% 13,3$ 'ü teorik çalışma olarak hazırlanmış olup herhangi bir yöntem kullanılmamıştır.

Tablo 11. Lisansüstü Tezlerin Araştırma Yöntemlerine Göre Dağılımı

\begin{tabular}{lcccccc}
\hline \multirow{2}{*}{ Araştırma Yöntemi } & \multicolumn{2}{c}{ Yüksek Lisans } & \multicolumn{2}{c}{ Doktora } & \multicolumn{2}{c}{ Toplam } \\
\cline { 2 - 7 } & $\mathrm{n}$ & $\%$ & $\mathrm{n}$ & $\%$ & $\mathrm{n}$ & $\%$ \\
\hline Nicel & 28 & 62,2 & 1 & 33,3 & 29 & 60,5 \\
\hline Nitel & 10 & 22,3 & 1 & 33,3 & 11 & 22,9 \\
\hline Nicel-Nitel & 1 & 2,2 & 1 & 33,4 & 2 & 4,1 \\
\hline Teorik Çalışma & 6 & 13,3 & - & - & 6 & 12,5 \\
\hline Toplam & $\mathbf{4 5}$ & $\mathbf{1 0 0}$ & $\mathbf{3}$ & $\mathbf{1 0 0}$ & $\mathbf{4 8}$ & $\mathbf{1 0 0}$ \\
\hline
\end{tabular}

İnanç turizmi ekseninde hazırlanan tezlerde kullanılan veri toplama tekniklerinde (Tablo 12) $\% 69,0$ oranla en sık kullanılan veri toplam tekniği anket olarak ortaya çıkmıştır. Bu tekniği $\% 11,9$ ilen yarı yapılandırılmış mülakat ve $\% 9,5$ oranla yapılandırılmış mülakat yöntemleri izlemiştir.

Tablo 12. Lisansüstü Tezlerin Veri Toplama Tekniklerine Göre Dağılımı

\begin{tabular}{lcccccc}
\hline \multirow{2}{*}{ Veri Toplama Tekniği } & \multicolumn{2}{c}{ Yüksek Lisans } & \multicolumn{2}{c}{ Doktora } & \multicolumn{2}{c}{ Toplam } \\
\cline { 2 - 7 } & $\mathrm{n}$ & $\%$ & $\mathrm{n}$ & $\%$ & $\mathrm{n}$ & $\%$ \\
\hline Anket & 28 & 71,7 & 1 & 33,4 & 29 & 69,0 \\
\hline Yapılandırılmış Mülakat & 4 & 10,5 & - & - & 4 & 9,5 \\
\hline Yarı Yapılandırılmış Mülakat & 5 & 12,8 & - & - & 5 & 11,9 \\
\hline Yapılandırılmamış Mülakat & 1 & 2,5 & 1 & 33,3 & 2 & 4,8 \\
\hline Anket-Yapılandırılmış Mülakat & 1 & 2,5 & 1 & 33,3 & 2 & 4,8 \\
\hline Toplam & $\mathbf{3 9}$ & $\mathbf{1 0 0}$ & $\mathbf{3}$ & $\mathbf{1 0 0}$ & $\mathbf{4 2}$ & $\mathbf{1 0 0}$ \\
\hline
\end{tabular}


İnanç turizme yönelik verilerin toplanmasında başvurulan veri kaynaklarında (Tablo 13) ilk sırada inanç turizmine katılan yerli turistler \%34,0 oranla yer almıştır. Yerel halk ise \%27,3'lük oranla başvurulan ikinci kaynak olmuştur. Diğer bir öne çıkan kaynak ise \%13,7 ile seyahat acentaları olmuştur. Yabancı turistler ve turist rehberleri \%2,3 ile en az başvurulan veri kaynağ 1 olmuştur. Oysaki yabancı turistler ve turist rehberleri inanç turizminde önemli dinamiklerdir. $\mathrm{Bu}$ veri kaynaklarına başvurulması önemli bir gerekliliktir.

Tablo 13. Lisansüstü Tezlerin Veri Toplama Kaynaklarına Göre Dağılımı

\begin{tabular}{lcccccc}
\hline \multirow{2}{*}{ Veri Toplama Kaynağı } & \multicolumn{2}{c}{ Yüksek Lisans } & \multicolumn{2}{c}{ Doktora } & \multicolumn{2}{c}{ Toplam } \\
\cline { 2 - 7 } & $\mathrm{n}$ & $\%$ & $\mathrm{n}$ & $\%$ & $\mathrm{n}$ & $\%$ \\
\hline Yerli Turistler & 14 & 35,8 & 1 & 0,20 & 15 & 34,0 \\
\hline Yabanc1 Turistler & 1 & 2,6 & - & - & 1 & 2,3 \\
\hline Yerli Turistler-Yabanc1 Turistler & 4 & 10,2 & - & - & 4 & 9,0 \\
\hline Yetkili Resmi Kurumlar/Temsilcileri & 2 & 5,2 & 1 & 0,20 & 3 & 6,8 \\
\hline Yerel Halk & 11 & 28,2 & 1 & 0,20 & 12 & 27,3 \\
\hline Seyahat Acentalar1 & 5 & 12,8 & 1 & 0,20 & 6 & 13,7 \\
\hline Turist Rehberleri & 1 & 2,6 & - & - & 1 & 2,3 \\
\hline Akademisyenler & 1 & 2,6 & 1 & 0,20 & 2 & 4,6 \\
\hline Toplam & $\mathbf{3 9}$ & $\mathbf{1 0 0}$ & $\mathbf{5}$ & $\mathbf{1 0 0}$ & $\mathbf{4 4}$ & $\mathbf{1 0 0}$ \\
\hline Inanç turizm temat
\end{tabular}

İnanç turizm temalı hazırlanmış lisansüstü tezlerde yer alan anahtar kelimelerde 4 tezin erişime kapalı olması ve 3 tane tezin içinde anahtar kelime verilmemesi nedeniyle bibliyometrik değerlendirme toplam 44 tez üzerinden gerçekleştirilmiştir. Bu tezlerin (Tablo 14) 42 tanesi yüksek lisans ve 2 tanesi doktora tezi olmuştur. Anahtar kelimelerde 47 adet olmak üzere "inanç turizmi" anahtar kelimesi ilk sırada yer almıştır. Bu anahtar kelimeyi "turizm" 24 adet, "destinasyon" 5 adet, "destinasyon pazarlaması", "Hac ve Umre", "Seyahat Acenta/Acentaları" ve "Kastamonu" anahtar kelimeleri 3'er adet olarak izlemiştir.

Tablo 14. Lisansüstü Tezlerin Kullanılan Anahtar Kelimelere Göre Dağılımı

\begin{tabular}{|c|c|c|}
\hline Tez Türü & $\begin{array}{l}\text { Tez Tema } \\
\text { Kodu }\end{array}$ & Anahtar Kelimeler \\
\hline \multirow{3}{*}{ Doktora } & İnanç Turizmi & Etkinlik Turizmi, İnanç Turizmi, İnanç Etkinlikleri, Hac. \\
\hline & Dini Turizm & - \\
\hline & Helal Turizm & $\begin{array}{l}\text { Helâl, Helâl Turizm, Helâl Standardizasyon, Helâl Uygulamaları, } \\
\text { Konaklama İşletmeleri. }\end{array}$ \\
\hline \multirow{6}{*}{$\begin{array}{l}\text { Yüksek } \\
\text { Lisans }\end{array}$} & \multirow{6}{*}{ İnanç Turizmi } & Turizm, İnanç Turizmi, İznik, Ekümenik Konsil, Nikaia, \\
\hline & & İnanç Turizmi, İnanç, Mersin. \\
\hline & & Turizm Ekonomisi, Kültür Turizmi, İnanç Turizmi, Diyarbakır. \\
\hline & & Turizm, İnanç Turizmi, Demre, Myra, St. Nikolas, Noel Baba. \\
\hline & & $\begin{array}{l}\text { Turizm, Alternatif Turizm, İnanç Turizmi, Seyahat Acentaları, } \\
\text { Kuşadası, İzmir, }\end{array}$ \\
\hline & & Turizm, Tanıtma, Turistik Tanıtma, İnanç Turizmi, Aziz Pavlus. \\
\hline
\end{tabular}




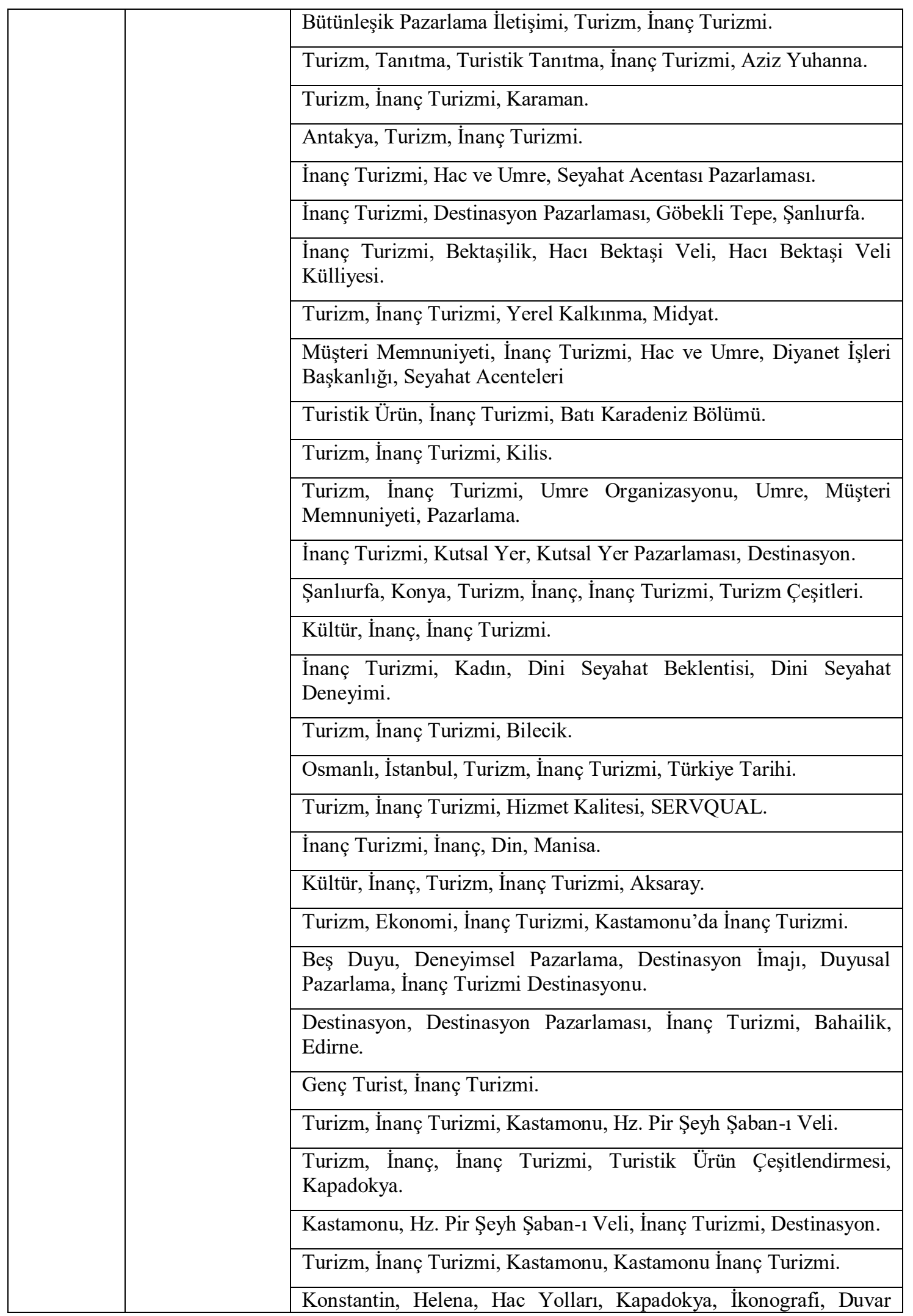

December-2020 Vol:5 No:2 International Journal of Turkic World Tourism Studies 


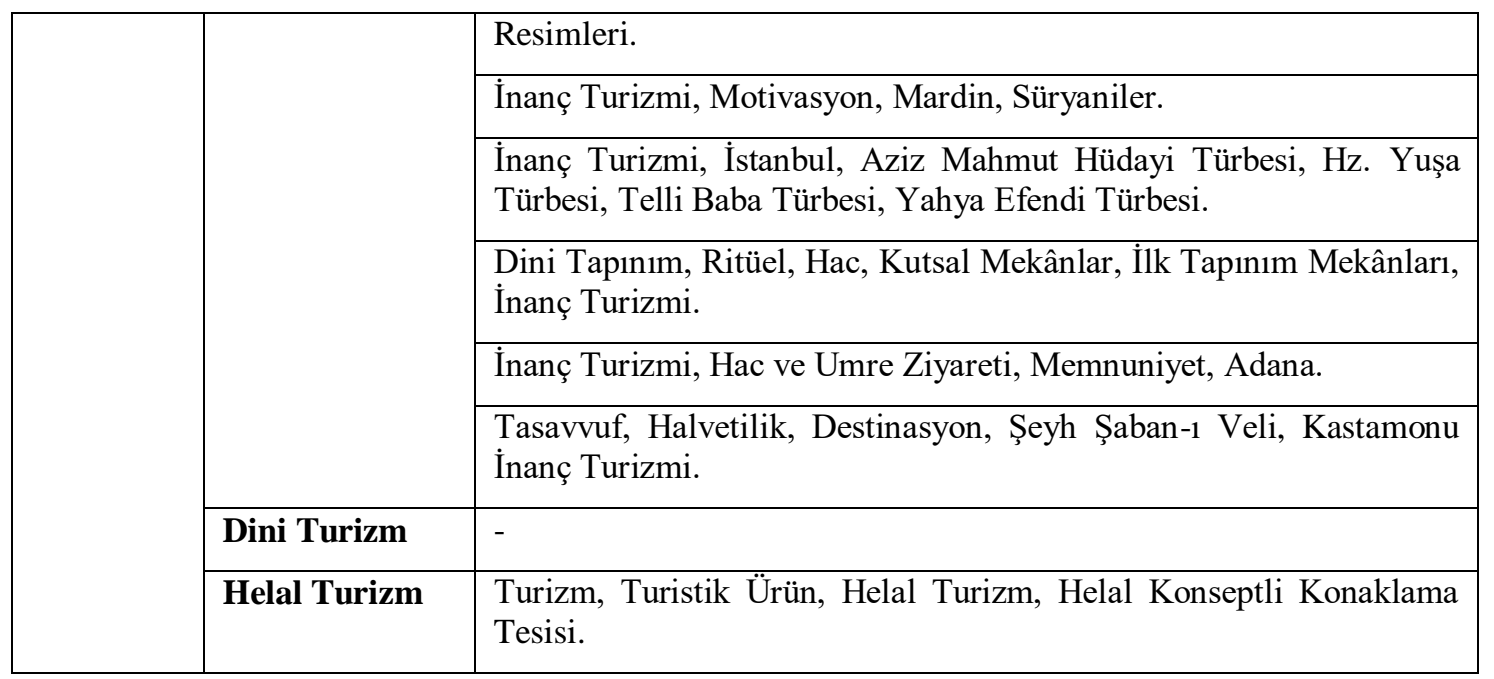

İnanç turizme yönelik olarak hazırlanmış lisansüstü tezlerin yerli kaynak kullanma durumlarında (Tablo 15) 4 tezin erişime kapalı olması nedeniyle değerlendirme toplam 47 tez (Yüksek Lisans: 44; Doktora: 3) üzerinden gerçekleştirilmiştir. Tezlerin yerli kaynak kullanma durumunda 76-100 kaynak aralığı ilk sırada (\%29,7), 51-75 kaynak aralı̆̆ ikinci sirada (\%19,1) ve 0-50 ve 101-125 kaynak aralıkları \%17,1 aralıkla üçüncü sırada yer almıştır. Yüksek lisans tezlerinde göze çarpan yerli kaynak kullanımı \%31,8 oranla 76-100 aralığında olurken doktora tezlerinde 0-50 kaynak, 51-75 kaynak ve 151 ve üzeri kaynak kullanımı olmak üzere dağılım gözlemlenmiştir.

Tablo 15. Lisansüstü Tezlerin Yerli Kaynak Kullanımına Göre Dağılımı

\begin{tabular}{lcccccc}
\hline \multirow{2}{*}{ Yerli Kaynak Sayısı } & \multicolumn{2}{c}{ Yüksek Lisans } & \multicolumn{2}{c}{ Doktora } & \multicolumn{2}{c}{ Toplam } \\
\cline { 2 - 7 } & $\mathrm{n}$ & $\%$ & $\mathrm{n}$ & $\%$ & $\mathrm{n}$ & $\%$ \\
\hline $0-50$ & 7 & 15,9 & 1 & 0,33 & 8 & 17,1 \\
\hline $51-75$ & 8 & 18,2 & 1 & 0,33 & 9 & 19,1 \\
\hline $76-100$ & 14 & 31,8 & - & - & 14 & 29,7 \\
\hline $101-125$ & 8 & 18,2 & - & - & 8 & 17,1 \\
\hline $126-150$ & 3 & 6,8 & - & - & 3 & 6,4 \\
\hline 151 ve üzeri & 4 & 9,1 & 1 & 0,34 & 5 & 10,6 \\
\hline Toplam & $\mathbf{4 4}$ & $\mathbf{1 0 0}$ & $\mathbf{3}$ & $\mathbf{1 0 0}$ & $\mathbf{4 7}$ & $\mathbf{1 0 0}$ \\
\hline
\end{tabular}

İnanç turizme yönelik lisansüstü tezlerin yabancı kaynak kullanma durumlarında (Tablo 16) yerli kaynakça dağılımında olduğu gibi 4 tezin erişime kapalı olması nedeniyle değerlendirmeye alınmamıştır. Değerlendirme Yüksek Lisans: 44 ve Doktora: 3 olmak üzere toplam 47 tez üzerinden gerçekleştirilmiştir. Tezlerin yabancı kaynak kullanma durumunda yüksek lisans tezlerinde $0-25$ aralığı ilk sırada $(\% 72,7)$ ve $26-50$ aralığ ikinci sırada $(\% 11,3)$ yer almıştır. Doktora tezlerinde ise yabancı kaynak kullanımı \%67,8 oranla 101 ve üzeri aralığında şekillenmiştir. $\mathrm{Bu}$ sonuçlar kapsamında özellikle yüksek lisans tezler için yabancı kaynak kullanımın yetersiz kaldığını söylemek mümkündür. Türkiye'de alternatif bir turizm çeşidi olarak gelişmeye başlayan inanç turizminde dünyada rekabetçi bir konum oluşturabilmek için daha fazla yabancı kaynağın taranması ve bilgilerin Türkiye destinasyonuna taşınması önemli bir gereklilik olarak görülebilir. Bu çerçevede danışmanların öğrencilerini yabancı kaynak kullanmaya teşvik etmesi gerekmektedir. 
Tablo 16. Lisansüstü Tezlerin Yabancı Kaynak Kullanımına Göre Dağılımı

\begin{tabular}{lcccccc}
\hline \multirow{2}{*}{ Yabancı Kaynak Sayısı } & \multicolumn{2}{c}{ Yüksek Lisans } & \multicolumn{2}{c}{ Doktora } & \multicolumn{2}{c}{ Toplam } \\
\cline { 2 - 8 } & $\mathrm{n}$ & $\%$ & $\mathrm{n}$ & $\%$ & $\mathrm{n}$ & $\%$ \\
\hline $0-25$ & 32 & 72,7 & - & - & 32 & 68,1 \\
\hline $26-50$ & 5 & 11,3 & - & - & 5 & 10,6 \\
\hline $51-75$ & 3 & 6,9 & 1 & 0,33 & 4 & 8,5 \\
\hline $76-100$ & 3 & 6,9 & - & - & 3 & 6,4 \\
\hline 101 ve üzeri & 1 & 2,2 & 2 & 0,67 & 3 & 6,4 \\
\hline Toplam & $\mathbf{4 4}$ & $\mathbf{1 0 0}$ & $\mathbf{3}$ & $\mathbf{1 0 0}$ & $\mathbf{4 7}$ & $\mathbf{1 0 0}$ \\
\hline
\end{tabular}

Türkiye'de inanç turizmi kapsamındaki tezlerin içerik analizi çerçevesinde çalışılan illere göre dağılımında (Tablo 17) İzmir ve Kastamonu \%13,5 oranla ilk sırada yer almıştır. Bu illeri Nevşehir $(\% 8,5)$, İstanbul $(\% 4,1)$, Konya $(\% 4,1)$, Mardin $(\% 4,1)$, Mersin $(\% 4,1)$ ve Şanlıurfa $(\% 4,1)$ illeri takip etmiştir.

Tablo 17. Türkiye'de İnanç Turizmi Açısından Öne Çıkartılan İllere Yönelik İçerik Analizi Bulgular1

\begin{tabular}{|c|c|c|c|c|c|c|}
\hline \multirow[t]{3}{*}{ İnanç Turizmi/Çalışılan İller } & \multicolumn{4}{|c|}{ Tez Türü } & \multirow{2}{*}{\multicolumn{2}{|c|}{ Toplam }} \\
\hline & \multicolumn{2}{|c|}{ Yüksek Lisans } & & \multirow{2}{*}{$\begin{array}{r}\text { Doktora } \\
\%\end{array}$} & & \\
\hline & $\mathbf{n}$ & $\%$ & $\mathbf{n}$ & & $\mathbf{n}$ & $\%$ \\
\hline Adana & 1 & 2,0 & & & 1 & 2,0 \\
\hline Aksaray & 1 & 2,0 & & & 1 & 2,0 \\
\hline Antalya & 1 & 2,0 & & & 1 & 2,0 \\
\hline Bartın & 1 & 2,0 & & & 1 & 2,0 \\
\hline Bilecik & 1 & 2,0 & & & 1 & 2,0 \\
\hline Bolu & 1 & 2,0 & & & 1 & 2,0 \\
\hline Bursa & 1 & 2,0 & & & 1 & 2,0 \\
\hline Diyarbakır & 1 & 2,0 & & & 1 & 2,0 \\
\hline Düzce & 1 & 2,0 & & & 1 & 2,0 \\
\hline Edirne & 1 & 2,0 & & & 1 & 2,0 \\
\hline Erzurum & 1 & 2,0 & & & 1 & 2,0 \\
\hline Hatay & 1 & 2,0 & 1 & 100 & 2 & 4,0 \\
\hline İzmir & 6 & 14,5 & & & 6 & 13,5 \\
\hline İstanbul & 4 & 4,1 & & & 4 & 4,1 \\
\hline Kahramanmaraş & 1 & 2,0 & & & 1 & 2,0 \\
\hline Karabük & 1 & 2,0 & & & 1 & 2,0 \\
\hline Karaman & 1 & 2,0 & & & 1 & 2,0 \\
\hline Kastamonu & 6 & 14,5 & & & 6 & 13,5 \\
\hline Kayseri & 1 & 2,0 & & & 1 & 2,0 \\
\hline Kirklareli & 1 & 2,0 & & & 1 & 2,0 \\
\hline Kilis & 1 & 2,0 & & & 1 & 2,0 \\
\hline Konya & 2 & 4,1 & & & 2 & 4,1 \\
\hline Manisa & 1 & 2,0 & & & 1 & 2,0 \\
\hline Mardin & 2 & 4,1 & & & 2 & 4,1 \\
\hline Mersin & 2 & 4,1 & & & 2 & 4,1 \\
\hline Nevşehir & 3 & 8,5 & & & 3 & 8,5 \\
\hline Sinop & 1 & 2,0 & & & 1 & 2,0 \\
\hline Şanlıurfa & 2 & 4,1 & & & 2 & 4,1 \\
\hline Zonguldak & 1 & 2,0 & & & 1 & 2,0 \\
\hline Toplam & 48 & 100 & 1 & 100 & 49 & 100 \\
\hline
\end{tabular}

December-2020 Vol:5 No:2 International Journal of Turkic World Tourism Studies 
Türkiye'de alternatif turizm geliştirme, tanıtım, imaj, pazarlama, hizmet kalitesi, etkinlik geliştirme, koruma ve farkındalık oluşturma temaları doğrultusunda hazırlanmış olan lisansüstü tezlerinde inanç turizminin önemi, sorunları ve Türkiye'de geliştirilmesine yönelik içerik analizi bulguları şu şekilde tespit edilmiştir:

-İnanç turizminin öneminde; dinlerin doğduğu alanlara yakınlık, üç önemli Semavi olan İslamiyet, Hristiyanlık ve Musevilik eserlerinin varlığı, Hristiyanlık dinine yönelik dokuz adet Hac merkezinin bulunması, Mardin'in, Süryanilerin dini merkezi durumunda olması, İslamiyet dini için 200, Hristiyanlık dini için 134, Musevilik dini için 17 ve diğer dinler için 5 adet önemli ziyaret merkezinin bulunması, Türkiye'ye kolay ulaşılabilirlik, genellikle konaklama tesislerinin ve insan kaynaklarının yeterliliği

-İnanç turizminin sorunlarında; inanç merkezlerinde alt yapı yetersizliği ve güvenlik sorunu, yerel halkta inanç turizmi konusunda bilinç eksikliği, yabancı dil bilen personel yetersizliği, seyahat acentalarının tur planlaması hataları, inanç merkezlerinde çevre temizliğinin yetersizliği, tanıtım eksikliği, kalifiye personel yetersizliği, inanç turizmi konusunda turistleri bilgilendirebilecek rehber eksikliği, inanç merkezlerindeki yönlendirme tabelalarının yeterli olmaması, inanç merkezleri yakınında turistlere hizmet sunabilecek işletmelerin yetersizliği ve inanç turizmine yönelik akademik çalışmaların azlığı.

-Türkiye'de inanç turizminin geliştirilmesine yönelik önerilerde; inanç alanlarında alt yapı yetersizlikleri (konaklama, yiyecek ve içecek, tuvalet, alışveriş vb.) ortadan kaldırılmalı, inanç turizmi iç pazarda hareketlendirilmeli, Ayasofya'nın müze olması yanında ibadete de açılması, inanç eserleri için uygun restorasyon yapılması ve gelecek kuşaklar için korunması, yerel halkın inanç turizmi ve turistler konusunda bilgilendirilmesi, ulusal ve uluslararası düzeyde tanıtım yapılması, inanç alanlarında güvenliğin sağlanması, inanç mekanlarında din görevlilerinin bulunmasını sağlama, turistlerden geri bildirimler alınması ve düzeltici önlemlere başvurulması, inanç temalı hediyelik eşyalar hazırlanması, profesyonel rehberlerin kullanılması, inanç turistlerinin konaklama süresini uzatabilecek faaliyetlerin artırılması ve turizm eğitimi veren kurumlardan destek sağlanması.

\section{SONUÇ VE ÖNERILER}

Dünyada turizminde önemli bir varış noktası olan Türkiye destinasyonu için alternatif turizm türlerinden bir tanesi de inanç turizmidir. Bu anlamda inanç turizmine yönelik bilimsel çalışmalar, önemli bir gereklilik olarak görülebilir. Çeşitli dinlerdeki kutsallar etrafında şekillenen inanç turizmi için bilimsel bilginin artması, dini yerlerin yöneticilerine, destekleyicilere ve işletmecilere yol gösterici olabilir.

İnanç turizmi kapsamında hazırlanmış alternatif turizm geliştirme, tanıtım, imaj, pazarlama, hizmet kalitesi, etkinlik geliştirme, koruma ve farkındalık oluşturma temaları doğrultusundaki lisansüstü tezlerin bibliyometrik analiz ve içerik analizi kapsamında değerlendirilmesinin yapıldığı bu çalışmada ulaşılan bulgular etrafında inanç turizmi için şu öneriler sunulabilir:

-Türkiye'de halihazırda inanç turizmine yönelik tezlerin büyük çoğunluğu yüksek lisans tezidir. $\mathrm{Bu}$ durum kapsamında doktora tezleri göreceli olarak artırılmalıdır.

-İnanç turizmi tezleri çoğunlukla Sosyal Bilimler Enstitüsü bünyesinde Turizm İşletmeciliği Anabilim Dalı kapsamında hazırlanmıştır. Farklı disiplinlerde de (Temel İslam Bilimleri, Etik Değerler, Sanat Tarihi, Coğrafya, Tarih) inanç turizminin çalışılması teşvik edilmelidir. 
-Alternatif turizm geliştirme, tanıtım, imaj, pazarlama, hizmet kalitesi, etkinlik geliştirme, koruma ve farkındalık oluşturma amaçları ekseninde şekillenen inanç turizmi tezleri turist beklentileri yönüyle çalışılmalıdır.

-Lisansüstü tezler için birincil verilerin toplanmasında çoğunlukla yerel kaynaklara (yerli turistler, yerel yöneticiler, yerel halk) başvurulmuştur. Yabancı turistler ve turist rehberlerinden veri sağlayan test sayısı oldukça sınırlıdır. Gelecekte hazırlanacak tezlerde yabancı turistlerden hareket edilmesi, Türkiye'deki inanç turizminin gelişimine katkı sağlayabilecektir. Özellikle doktora tezlerinde bu durum öne çıkarılmalıdır. Çünkü, yabancı turistler ve turist rehberleri inanç turizminde önemli dinamiklerdir.

-Bu araştırmada Yükseköğretim Merkezi Ulusal Tez Merkezinin veri tabanında yer almakta olan inanç turizmine yönelik tezler, bibliyometrik ve içerik analizi kapsamında incelenmiştir. Gelecekte inanç turizmine yönelik lisansüstü tezlerin uluslararası nitelikteki tezlerin yayımlanmış olduğu "Proquest Dissertation" veri tabanın analiz birimi olarak kullanılması ve sonuçlarının bu tez çalışması ile mukayese edilmesi inanç turizmi literatürüne farklı bir bakış açısı oluşturabilir.

\section{KAYNAKÇA}

Abbate, C. S. ve Nuovo S. F. (2013). Motivation and personality traits for choosing religious tourism. A research on the case of Medjugorje. Current Issues in Tourism, 16(5), 501-506.

Aslantürk, Y., Altınöz, Ö., Bülbül, S. ve Güral, F. N. (2013). İnanç turizmi ile ilgili Türkiye'de yapılan akademik çalışmaların incelenmesi. International Conference on Religious Tourism and Tolerance Proceedings, Konya, 9-12 May.

Avcı, M. (2019). Vuslatının 450.Yıldönümünde Hz. Pir Şeyh Şaban-1 Veli Yılı (Fikri, Teklifi ve Çabası Serüveni), Ankara: Ses Reklam ve Matbaacılık Ltd.

Ayaz, N. (2015). Milli Eğitim Şurası kararlarında mesleki eğitimin düşünsel yapısı ve turizm eğitimi. Turizm Akademik Dergisi, 2(2), 45-57.

El-Gohary, H. (2016). Halal tourism, is it really Halal? Tourism Management Perspectives, 19(2016), 124-130.

Gisbert. R. (1992). Forms of religious tourism. Annals of Tourism Research, 19(1), 51-67.

Gürbüz, S. ve Aydın. B. O. (2018). İslami inanç destinasyonlarının tanıtımında Youtube videolarının kullanımı. Gümüşhane Üniversitesi İletişsim Fakültesi Elektronik Dergisi, 6(1), 539-568.

Harris, H. (2001). Content analysis of secondary data: A study of courage in managerial decision making. Journal of Business Ethics, 34(3), 191-208.

Hughes, K., Bond, N. ve Ballantyne, R. (2013). Designing and managing interpretive experiences at religious sites: Visitors' perceptions of Canterbury Cathedral. Tourism Management, (36), 210220.

https://cemalakin.wordpress.com/2016/04/26/inanc-turizminde-dunya-ve-turkiye-destinasyonu/ [Erişim Tarihi: 26.12.2019].

Jafari, J. (2000). Encyclopedia of Tourism. London, GBR: Routledge.

Karaman, S., Demirkol Ş. ve Şahin S. (2008). İnanç turizmi. N. Hacıŏlu ve C. Avcıkurt (Editörler), Turistik Ürün Çeşitlendirmesi (s.209-238), Ankara: Nobel Yayın Dağıtım.

Kim, B. ve Kim, S. (2019). Hierarchical value map of religious tourists visiting the Vatican City/Rome, Tourism Geographies, 21(3), 529-550. 
Koçoğlu C. M., Bakkaloğlu, F. ve Acar, A. (2019). Yerel halkın inanç turizmine yönelik bakış açılarının demografik özelliklere göre değerlendirilmesi. Gümüşhane Üniversitesi Sosyal Bilimler Enstitüsü Elektronik Dergisi, 10(Ek Say1), 124-131.

Mokhlis, S. (2009). Relevancy and measurement of religiosity in consumer behavior research. International Business Research, 2(3), 75-84.

Okuyucu. A. ve Somuncu, M. (2013). Türkiye'de inanç turizmi: Bugünkü durum, sorunlar ve gelecek. International Conference on Religious Tourism and Tolerance Proceeding (s.627-643), Konya, 9-12 Mayls.

Ruiz-Real, J. L., Uribe-Toril, J., Valenciano J. D. P. ve Gázquez-Abad, J. C. Worldwide research on circular economy and environment: A bibliometric analysis. International Journal of Environmental Research and Public Health, 15(2699), 1-14.

Timothy, D. ve Olsen, D. (2006). Tourism and Religious Journeys. London-New York: Routledge.

UNWTO. (2008). International Conference on Tourism, Religions and Dialogue of Cultures, Cordoba, Spain, 29-31 October 2007. Madrid: World Tourism Organization.

Wang, W., Chen, J. S. ve Huang, K. (2016). Religious tourist motivation in Buddhist Mountain: The case from China. Asia Pacific Journal of Tourism Research, 21(1), 57-72. 